\title{
AN ANALYSIS OF ATTITUDE TOWARDS ONLINE SHOPPING IN PAKISTAN USING THE TECHNOLOGY ACCEPTANCE MODEL
}

\section{Usman M. Nooruddin}

\begin{abstract}
This empirical study aims to examine the factors that Online Shopping Users exhibit which can be used to help the online shopping platforms further work on their online presence in order to make sure that all potential users stay on their platforms and most of all, are content using their platforms. Personality, Web Experiences, Perceived Usefulness, Perceived Ease of Use, Attitude were used to determine how these factors affect Online Shoppers. A survey (Google Forms) was distributed via social media and social messengers which comprised of virtually infinite respondents. The results showed that most of our respondents are not akin to finding the perceived usability or perceived ease of use of online shopping irrespective they have a certain online leadership style, or are impulsive buyers, and are also not deterred even if they are satisfied with a website or are security conscious. But if they end up finding an online system useful and user-friendly, they will definitely intend to come back to the online portal again for future purchases. This research was conducted inside Pakistan comprising respondents distributed in different cities due to the questionnaire being circulated via online mediums. Future researchers can employ the same model to conduct the same research in another country. This study proposes a framework to quantitatively analyzing the link between different aspects of Personality and different aspects of Web Experiences with Perceived Usefulness and Perceived Ease of Use, and furthermore the Attitude of the respondents towards Online Shopping Platforms.
\end{abstract}

Keywords: Online Shopping, Ecommerce, Personality Traits, Web Experiences, Perceived Ease of Use, Perceived Usefulness, Government Support \& Infrastructure, Technology Acceptance Model. 


\section{INTRODUCTION}

When it comes to Online Banking, it has been a core business platform since the advent of the Internet, where first it materialized as a place for ads for people to view and then evolving over the course of decades to support full multinational companies such as Amazon, eBay, Ali Baba to hold over a stock worth trillions of US Dollar ready to be shipped anywhere (Alibaba Group, n.d.). This study was thus conducted to analyze the market of Pakistan, and especially to analyze the people who are using Online Shopping in order to understand what motivates them to finally click the 'Add to Cart' button, and why some people might choose otherwise. One of the reasons why this research was conducted was to see what are the leading online platforms such as Daraz.com doing right to have become a household name instead of the various other Online Platforms out there, which causes most people to purchase from them instead of even bothering to check on other substitutes. This information then can be shared with the relevant people in question to discuss how they might 'up their online game' by modifying their business model to attract more customers, more importantly provide the atmosphere that the customer finds settling.

\section{Background of the Study}

The internet provides an ever-expanding playing field for every single player out there, but only the best is able to become brands or household names. It's Amazon in the US, Amazon and eBay in Europe, AliBaba in most parts of Asia, Souq.com in the Middle East and Daraz in Pakistan. A point to note here is that most of these names are not sole entities in the market, but are surrounded by sister brands and competitors vying for a space in the potential persons' website bookmark, or a place on their mobile screens (Pakistani Market: E-Commerce, n.d.). But what we observe in Pakistan especially that the companies that claim to have a huge infrastructure behind them also fail to capture their customers' attention, despite exceptionally low prices coupled with discounts trying to undercut their competitors. What we have observed 
is that when we ask around people in our immediate vicinity, we hear that a certain Online Platform is most easy to use platform out there, since whatever the customer is trying to find, they find it easily - showing that there is a definite element of user friendliness in the equation other than usefulness, where usefulness can be seen as the result and/or return from someone's work pertaining to a certain activity (Davis, 1989).

\section{Statement of the Problem}

Ideally speaking, there should be an equal distribution of consumers per online shopping platforms in Pakistan, but we see a massive discrepancy here, to a point we might mistake the Online Shopping market to be monopolized. Online Shopping consumers should be aware that more online shopping platforms exist that might suit their needs better and ever have much more better prices than the ones that they are always insisting on using in every condition by default (Daraz.Pk Analytics - Market Share Data \& Ranking | SimilarWeb, n.d.).

\section{RESEARCH QUESTIONS}

1. To what extent is the personality of a person in play when we are considering the perceived usefulness of an online platform, and what impact does it play for that potential online shopper to form an intention to purchase.

2. How well versed should a person be when it comes to internet experiences to see the benefit of online shopping?

3. How well should an online shopping platform should be perceived as useful and easy to use in order for a potential online user to form an intention to purchase.

\section{OBJECTIVES OF THE STUDY}

Through this study, we aim to dive deep into the decision-making process, but from the Online Shopping Platforms point of view, since they are the ones that have to make the change. To achieve this, we will be analyzing the responses given to us by our respondents to map out the profile of an online shopper (the personality, web experiences) and relating to how much do 
they impact the usability and ease of use of an E-Commerce platform, concluding to what is necessary for them to form an intention to purchase from them.

\section{JUSTIFICATION OF THE STUDY}

Amongst rivalry of all the online shopping platforms, some have done real work to get where they are today, while others might have relied on luck. What we aim to do is try to understand a customers' preferences why they might stick to a certain online shopping platform, and what aspects do they might find a disliking to. This will also help new online platforms make the necessary adjustments in their online platforms to gain traction much faster since it will be closer to what their direct market is expecting (Forsythe et al., 2006).

\section{LIMITATIONS OF THE STUDY}

- This study is limited to the Online Shopping platforms in Pakistan, hence some aspects of it might need to be modified in order to be implemented in other countries.

- As time changes, there might be a necessity to repeat this entire research 'as is' due to either technological changes, or if the entire e-commerce system is revamped to further enhance the experience of online shopping.

- Although the study was conducted using a questionnaire, and communicated to others via online meaning that there was almost no researcher interference (non-contrived), there is still a chance that the respondent might have marked an answer without thoroughly understanding a questionnaire, or might have miscommunicated on purpose.

\section{SCOPE OF THE STUDY}

The scope of the study focuses on analyzing the approach and perception of customers towards online shopping. For this purpose, a Google Form questionnaire was circulated among different social media messengers such as WhatsApp, Facebook and Email. The questionnaire comprised of a total of 44 questions which were focused on gathering different relevant 
demographics about the person filling it in, and then asked questions pertaining to measure the respondent's take on Personality, Web Experiences, Perceived Ease of Use, Perceived Usefulness and Attitude towards Online Shopping.

\section{Assumptions}

It has been assumed that the Technology Acceptance Model (Davis, 1989) which is one of the most influential models in helping researchers to study technology acceptance, can be applied to study the different aspects of online shoppers in Pakistan.

\section{LITERATURE REVIEW \& HYPOTHESIS DEVELOPMENT}

Research work regarding the adoption of technologies is an undergoing process, which more or less started with the Technology Acceptance Model (Davis, 1989). Some implemented it to explore the nature of internet users (O'Cass et al., 2003) and some explored entire different aspects of it in order to further refine the TAM (Venkatesh \& Bala, 2008) in order to build upon the original and some revaluating the revised model to better explain it (Szajna, 1996). Online Shopping in Pakistan, once used to be a privilege, but as the online shopping platforms grew, brought in more people to use the facility ( $82 \%$ of Pakistani Urban Consumers Made an Online Purchase in 2018: Nielsen - Profit by Pakistan Today, n.d.; ECommerce - Pakistan Statista Market Forecast, n.d.; What Do We Know about Pakistan's Ecommerce Industry? Sponsored - Dawn.Com, n.d.). At the same time, due to the lockdowns due to COVID-19, the online shopping industry has boomed, despite the fear of growing inflation (Consumer Confidence Survey September, 2020). Since online shopping platforms are a growing industry (around the world and in Pakistan as well), a lot of research has also been performed along with it trying to explain the different aspects of the research.

Research on online shopping has been done linking different aspects of the potential shoppers' intentions to validating a successful purchase online, hence is also referred to as web-based purchasing behavior when consumer behavior is taken into context (Bashir, 2013), and having 
a multitude of benefits to the suppliers when customers are using online shopping platforms (Zhou et al., 2007). When considering the customers' point of view, there are also a multitude of advantages such as its mobile - anyone can search for anything anywhere while being the most convenient when it comes to searching and comparing different products. But with benefits come some disadvantages such as the purchasers find themselves gambling on some of the product since they cannot touch and or smell it (Guo et al., 2012).

Due to all the benefits, Online Shopping and its multitude of platforms are gaining a lot of traction, but with that, the need arises to further enhance and customize the online platforms in the potential users' best interests - to make the platform easy to use, and the user should feel that after using any online platform he/she was successful in using it the way he/she intended it to use (O’Cass \& Fenech, 2003).

\section{THEORETICAL BACKGROUND}

The theoretical background of this study starts with the original Technology Acceptance Model (Davis, 1989) that takes into consideration its three aspects namely, Perceived Ease of Use, Perceived Usefulness and Attitude towards adoption, which forms half of the conceptual framework. The other half of the conceptual framework is also based on the TAM, but the revised model (Szajna, 1996; Venkatesh \& Davis, 2000; Yu et al., 2005) that shows that there can be several factors that can be explored that can act as independent inputs to Perceived Usefulness and Perceived Ease of Use (Venkatesh \& Bala, 2008). As the commercial sector grows coupled with fast internet speeds and high functioning mobile devices (O'Cass et al., 2003), understanding how all of these factors come together is exceptionally important. 
Figure 1: The original Technology Acceptance Model (Davis, 1989)

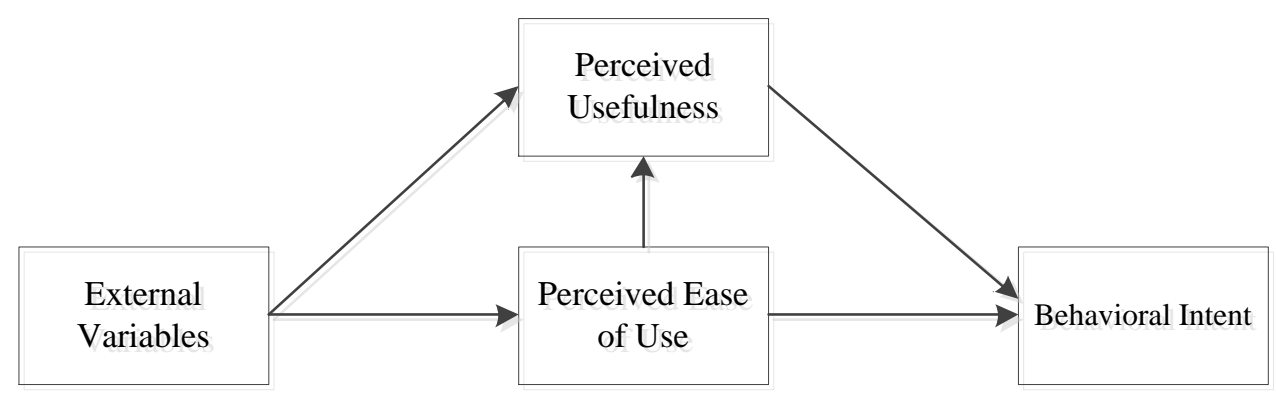

Figure 2: Technology Acceptance Model 3 (Venkatesh \& Bala, 2008)

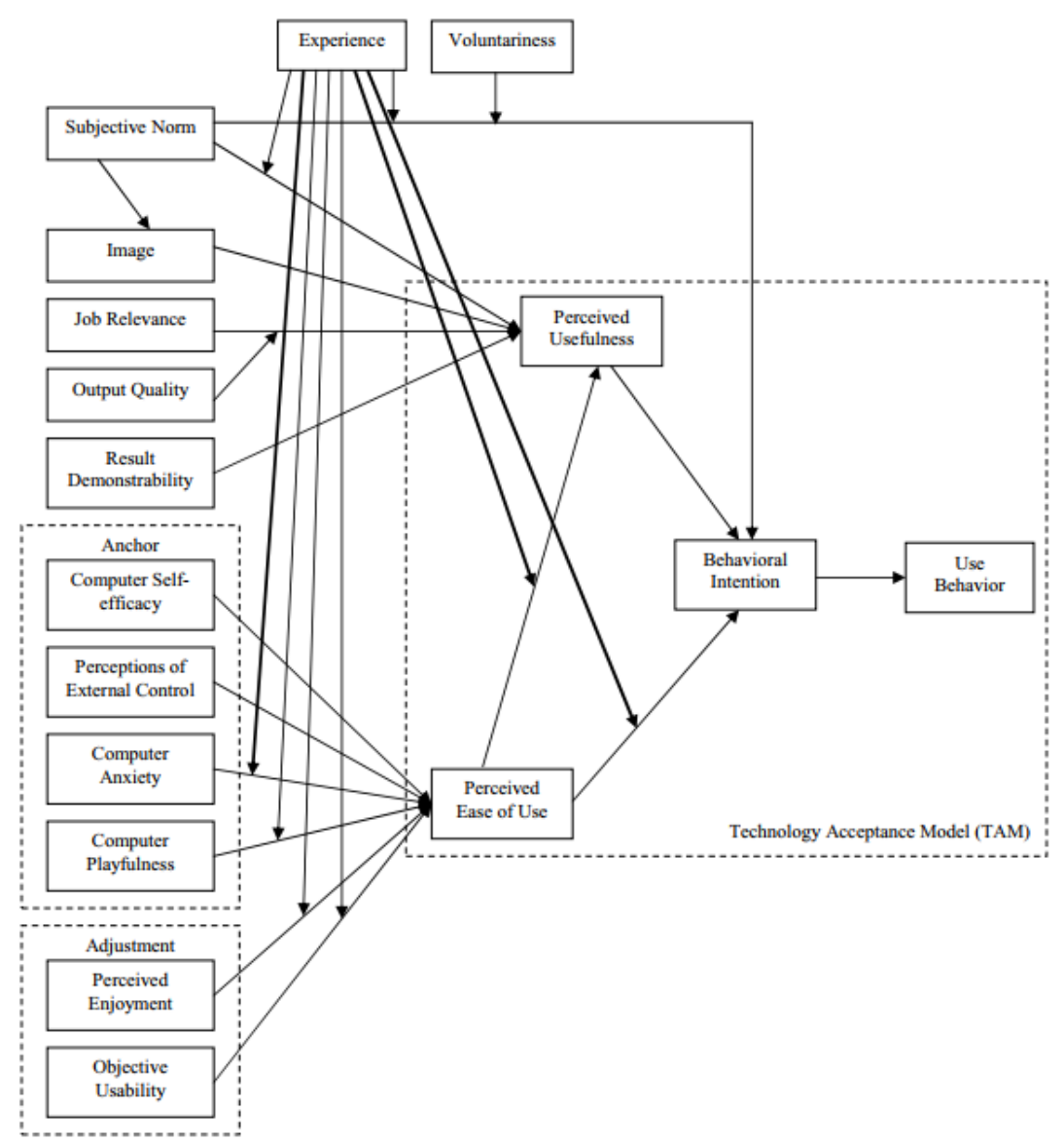

Personality $\rightarrow$ Perceived Usefulness; Personality $\rightarrow$ Perceived Ease of Use

Personality includes Opinion Leadership and Buying Impulsiveness (O’Cass et al., 2003) since for a person who is using Online Shopping, these two factors help define the person in general. 
As per the studies conducted at the time of adoption when home computers in the early 80 s

(Gentry \& Dickerson, 1983), it was concluded that opinion leaders literally lead the way in product adoption rates. On the other hand, buying impulsiveness (Beatty \& Ferrell, 1998) is when the purchaser disregards consequences and opts to make a purchase anyways, but online shopping portals have advertisements that lead any online shopper down the rabbit hole of items that are not required, but he/she purchases it anyways, similar to the early 90s when information advertisements was common on televisions (Donthu \& Gilliland, 1996).

All this relates with the TAM models (Szajna, 1996) through the perceived usefulness and ease of use as to how the personality factors will contribute towards both.

\section{H1 - Personality positively affects Perceived Usefulness}

H2 - Personality positively affects Perceived Ease of Use

\section{Web Experiences $\rightarrow$ Perceived Usefulness; Web Experiences $\rightarrow$ Perceived Ease of Use}

Web experiences includes Internet Self Efficacy, Perceived Web Security, Satisfaction with Websites, Web Shopping Compatibility (O'Cass et al., 2003) and due to this factor, measure the different factors that the users experience in finding Online Shopping easy to use and useful as described and discussed in the original and revised TAM (Davis, 1993; Davis \& Venkatesh, 1996). Different elements of different websites contribute to how the user interacting with that website feels (Lederer et al., 1997) and furthermore defines the attitude and adoption of that website.

\section{H3 - Web Experiences positively affects Perceived Usefulness}

H4 - Web Experiences positively affects Perceived Ease of Use

Perceived Usefulness $\rightarrow$ Attitude towards Online Shopping; Perceived Ease of Use $\rightarrow$ Attitude towards Online Shopping

Anyone that is using Online Shopping to fulfill his/her needs will always show a particular attitude towards it, and that is the determining factor whether if a person will user online 
shopping or not (Davis, 1989, 1993; Davis \& Venkatesh, 1996; Moon \& Kim, 2001; Szajna, 1996). But since Attitude is an unobserved variable of its own, it will be determined by the consumers Perceived Ease of Use and the Usefulness of any online shopping platforms.

A favorable attitude will be required to adopt or further adopt Online Shopping Platforms, and unfavorable attitude will result in users declining to use the same (Liker \& Sindi, 1997).

H5 - Perceived Usefulness positively affects Attitude towards Online Shopping

H6 - Perceived Ease of Use positively affects Attitude towards Online Shopping

Table 1: List of all the Hypotheses stated with references of their relationships

\section{Hypothesis Link Reference}

Personality $\rightarrow$

H1

Perceived Usefulness

1996)

Personality $\rightarrow$

(Donthu \& Gilliland, 1996; Gentry \& Dickerson,

H2

H3

H4
Web Experiences $\rightarrow$

Perceived Usefulness

Web Experiences $\rightarrow$

Perceived Ease of 1983; Moon \& Kim, 2001; O’Cass et al., 2003; Szajna,

Use 1996)

(Davis, 1993; Davis \& Venkatesh, 1996; Lederer et al., 1997; Moon \& Kim, 2001; O’Cass et al., 2003)

(Davis, 1993; Davis \& Venkatesh, 1996; Lederer et Perceived Ease of al., 1997; Moon \& Kim, 2001; O'Cass et al., 2003) 
Perceived Usefulness

H5

(Davis, 1989, 1993; Davis \& Venkatesh, 1996; Moon

Attitude $\quad$ towards \& Kim, 2001; Szajna, 1996)

Online Shopping

Perceived Ease of

$\mathrm{Use} \rightarrow$

(Davis, 1989, 1993; Davis \& Venkatesh, 1996; Moon

H6

Attitude towards \& Kim, 2001; Szajna, 1996)

Online Shopping

\section{CONCEPTUAL FRAMEWORK}

The literature depicts the relationship of Personality Traits with both Perceived Usefulness and Perceived Ease of Use. Web Experiences also depict its relationship with Perceived Usefulness and Perceived Ease of Use both. Perceived Usefulness and Perceived Ease of use both being mediating variable have a relationship with Attitude Towards Online Shopping Platforms.

\section{Figure 3: Proposed Hypothesized Conceptual Framework}

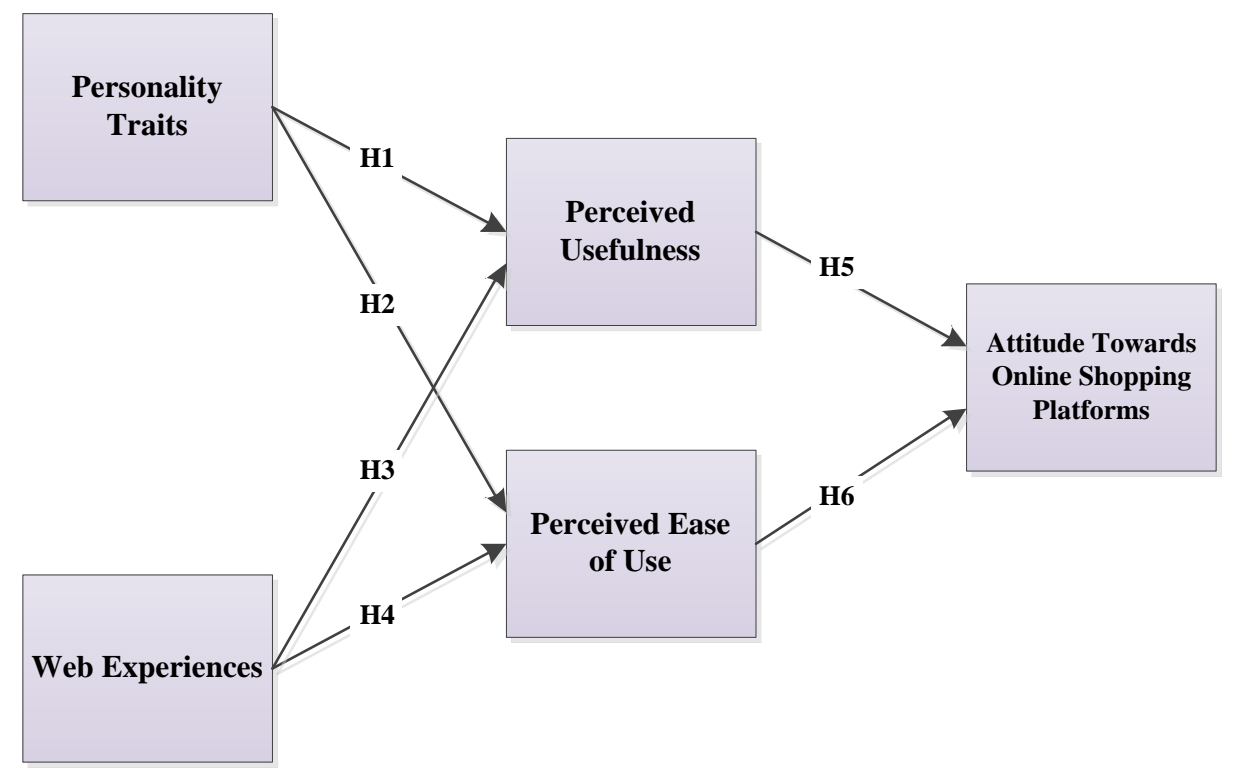




\section{RESEARCH METHODOLOGY}

\section{Research Design}

Since this is a quantitative research, we will be conducing theory testing, that is, a 'basic research' in order to test whether the relationship between two variables is significant or not via stating a hypothesis. To accomplish this, we will be gathering all our data using an online survey (Google Forms), hence all the data is primary data and collected firsthand. The objective of the research is to test what are the different factors in play when anyone uses online shopping, and how do then intend to use it.

The questionnaire will be distributed online via social media and social messengers such as WhatsApp and Facebook to expand our reachability to the respondents, but at the same time keeping it limited to the respondents inside Pakistan. And due to this, our research will be noncontrived, hence having no chance of influencing the choices our respondent makes while filling in the questionnaire. Post collection of data, it will be analyzed and furthermore all our stated hypotheses will be checked against to see whether if they were rejected, or did they fail to reject (Walpole \& Myers, 2012). Since all the constructs that have been used in this research are taken 'as is', this is a longitudinal study since we are reanalyzing different studies to check their results on a different environment.

\section{Population and Sample}

Convenience Sampling is used in order to reach our respondents since the questionnaire was broadcasted via online mediums to everyone, while at the same time, we requested everyone while reaching out to our respondents directly to pass on the questionnaire to anyone else who they knew used Online Shopping and ask them also to kindly fill in a response as well. Regarding the number of valid respondents, there are several opinions as to how many respondents are required for a proper sample size. One common criteria is to have 30 
respondents per construct (Sekeran, 2003), which puts this study at a $\left(5^{*} 30\right) 150$ respondents to fulfill this criteria.

\section{Instrumentation}

The instrument used for the research comprises of 5 constructs namely Perceived Usefulness (3 items), Perceived Ease of Use (3 items) adopted from Yu et al., (2005), Attitude Towards Online Shopping Platforms (3 items) adopted from Bashir, (2013), and two multidimensional constructs Personality Traits (11 items: Opinion Leadership (7 items), Buying Impulsiveness (4 items)) and Web Experiences (13 items: Web Satisfaction (3 items), Web Shopping Compatibility (3 items), Internet Self Efficacy (4 items), Perceived Web Security (3 items)) adopted from O'Cass et al., (2003).

As also referred in the Literature Review, Web Experiences and Personality Traits are independent variables, Perceived Ease of Use and Perceived Ease of Use are mediating variables, and Attitude towards Online Shopping Platforms is the dependent variable.

All the adopted constructs (Bashir, 2013; O'Cass et al., 2003; Yu et al., 2005) had a reliability of their Cronbach's Alpha greater than 0.7 which is a mandatory minimum criteria for any construct to be considered reliable (Santos, 1999).

\section{RESULTS}

\section{Descriptive Statistics}

To check whether if our collected data follows normality, a check is made to see whether if the skewness and kurtosis of the collected lies within the bounds. Skewness should be between -1 to +1 and Kurtosis should be between the bound of -3 to +3 .

In this case, the skewness for Internet Self Efficacy, Perceived Ease of Use and Attitude Towards Shopping whereas the kurtosis for perceived Ease of Use is out of bounds, indicating that out of the collected data, there are also outliers present as well which is affecting the normality of the dataset collected. 
Table 2: Descriptive Analysis of the Data Collected

\begin{tabular}{|c|c|c|c|c|c|}
\hline & Mean & Std. Deviation & Variance & Skewness & Kurtosis \\
\hline \multicolumn{6}{|l|}{ Personality Traits } \\
\hline Opinion Leadership & 4.62 & 1.38 & 1.91 & -0.55 & -0.54 \\
\hline Buying Impulsiveness & 4.09 & 1.65 & 2.71 & -0.20 & -1.12 \\
\hline \multicolumn{6}{|l|}{ Web Experience } \\
\hline Satisfaction with Websites & 4.04 & 1.30 & 1.68 & 0.33 & -0.83 \\
\hline Web Shopping Compatibility & 5.02 & 1.38 & 1.91 & -0.88 & 0.07 \\
\hline Internet Self Efficacy & 5.56 & 1.42 & 2.00 & -1.44 & 2.16 \\
\hline Perceived Web Security & 4.44 & 1.80 & 3.25 & -0.40 & -0.52 \\
\hline \multicolumn{6}{|l|}{ Technology Acceptance Model } \\
\hline Perceived Usefulness & 5.37 & 1.44 & 2.08 & -1.00 & 0.44 \\
\hline Perceived Ease of Use & 5.38 & 1.02 & 1.04 & -1.93 & 6.13 \\
\hline Attitude Towards Shopping & 5.19 & 1.19 & 1.40 & -1.32 & 2.75 \\
\hline
\end{tabular}

\section{Reliability of Constructs}

For any dataset, the items contained within a construct are considered reliable if and if they are measuring what they are intended to measure and how well they are measuring what they are designed to measure. For checking the reliability of a construct, the Cronbach's Alpha is calculated which should be greater than 0.7 (Hair et al., 2006; Santos, 1999). When the constructs were adopted from previously published studies (Bashir, 2013; O'Cass et al., 2003; Yu et al., 2005) it was made sure that the Cronbach's Alpha was greater than 0.7, and then rechecked in this study to find all of the constructs fulfilling that criteria except one 
subconstruct of Web Experience : Satisfaction with Websites that is slightly below the cutoff line.

The Cronbach's Alpha of Perceived Web Security was the highest at $(\alpha=0.95, M=22.26$, $\mathrm{V}=32.05, \mathrm{SD}=5.66)$ and as mentioned above, the lowest was for Satisfaction with Websites $(\alpha=0.66, M=12.11, V=15.10, \mathrm{SD}=3.89)$.

Table 3: Reliability Statistics of the Data Collected

\begin{tabular}{|c|c|c|c|c|c|}
\hline Constructs & $\begin{array}{l}\text { Cronbach's } \\
\text { Alpha }\end{array}$ & $\begin{array}{l}\text { No. of } \\
\text { Item }\end{array}$ & Mean & Variance & $\begin{array}{l}\text { Std. } \\
\text { Dev. }\end{array}$ \\
\hline \multicolumn{6}{|l|}{ Personality Traits } \\
\hline Opinion Leadership & 0.90 & 7 & 32.33 & 93.62 & 9.68 \\
\hline Buying Impulsiveness & 0.88 & 4 & 16.37 & 43.32 & 6.58 \\
\hline \multicolumn{6}{|l|}{ Web Experience } \\
\hline Satisfaction with Websites & 0.66 & 3 & 12.11 & 15.10 & 3.89 \\
\hline Shopping & 0.86 & 3 & 15.07 & 17.23 & 4.15 \\
\hline \multicolumn{6}{|l|}{ Compatibility } \\
\hline Internet Self Efficacy & 0.95 & 4 & 22.26 & 32.05 & 5.66 \\
\hline Perceived Web Security & 0.94 & 3 & 13.33 & 29.23 & 5.41 \\
\hline \multicolumn{6}{|l|}{ Technology Acceptance Model } \\
\hline Perceived Usefulness & 0.92 & 3 & 16.11 & 18.72 & 4.33 \\
\hline Perceived Ease of Use & 0.81 & 3 & 16.15 & 9.36 & 3.06 \\
\hline Attitude Towards Shopping & 0.92 & 3 & 15.56 & 12.64 & 3.56 \\
\hline
\end{tabular}

\section{Construct Validity}

For a construct to be considered valid, the Average Variance Extracted should be greater than 0.5, which at the same time its Composite Reliability should be greater than the Average 
Variance Extracted (Hair et al., 2006). In the data collected, we see that all of our constructs and subconstructs meet the mentioned requirements.

Table 5: Construct Validity Analysis

\begin{tabular}{|c|c|c|c|}
\hline Constructs & No. of Items & AVE & $\mathbf{C R}$ \\
\hline \multicolumn{4}{|l|}{ Personality Traits } \\
\hline Opinion Leadership & 7 & $58.2 \%$ & $90.2 \%$ \\
\hline Buying Impulsiveness & 4 & $64.5 \%$ & $87.9 \%$ \\
\hline \multicolumn{4}{|l|}{ Web Experience } \\
\hline Satisfaction with Websites & 3 & $54.5 \%$ & $74.4 \%$ \\
\hline Web Shopping Compatibility & 3 & $68.6 \%$ & $86.6 \%$ \\
\hline Internet Self Efficacy & 4 & $82.8 \%$ & $95.1 \%$ \\
\hline Perceived Web Security & 3 & $84.7 \%$ & $94.3 \%$ \\
\hline \multicolumn{4}{|l|}{ Technology Acceptance Model } \\
\hline Perceived Usefulness & 3 & $82.5 \%$ & $93.4 \%$ \\
\hline Perceived Ease of Use & 3 & $63.0 \%$ & $83.3 \%$ \\
\hline Attitude Towards Shopping & 3 & $78.8 \%$ & $91.8 \%$ \\
\hline
\end{tabular}

\section{Correlation Analysis}

To quickly summarize the direction and strength of a relationship between two constructs, we can employ the use of correlation, and to see whether if the variable in question is positively correlated or negatively correlated but most importantly if the correlation is even significant or not $(p<0.05)$. If two variables are significantly correlated with each other and their correlation coefficient $(\mathrm{R})$ is greater than 0.9 , those can be merged together since they are considered to be measuring the same effect (Bell et al., 2018). We can see that in the coefficients that do not follow a $*$ or $* *$ are insignificant hence have zero correlation between them, such as Buying 
Impulsiveness has no significant correlation with Perceived Usefulness, Satisfaction with Websites does not have any significant correlation with Internet Self-Efficacy, Perceived Usefulness, Perceived Ease of Use, Attitude towards Shopping, and Shopping Compatibility has does not have any significant correlation with Perceived Web Security.

Table 4: Correlation Analysis of the Data Collected

\begin{tabular}{|c|c|c|c|c|c|c|c|c|c|}
\hline Constructs & $\begin{array}{l}\text { PT } \\
\text { OL }\end{array}$ & $\begin{array}{l}\text { PT } \\
\text { BUY }\end{array}$ & $\begin{array}{l}\text { WEB } \\
\text { _SAT }\end{array}$ & $\begin{array}{l}\text { WE } \\
\text { B_S } \\
\text { C }\end{array}$ & $\begin{array}{l}\text { WEB } \\
\text { _ISE }\end{array}$ & $\begin{array}{l}\text { WEB } \\
\text { _PWS }\end{array}$ & $\begin{array}{l}\text { TAM_ } \\
\text { PUSE }\end{array}$ & $\begin{array}{l}\text { TAM } \\
\text { PEOU }\end{array}$ & $\begin{array}{l}\text { TAM } \\
\text { _ATT }\end{array}$ \\
\hline $\begin{array}{l}\text { Personality Traits - } \\
\text { Opinion Leadership }\end{array}$ & 1 & & & & & & & & \\
\hline $\begin{array}{l}\text { Personality Traits } \\
\text { Buying Impulsiveness }\end{array}$ & $.568^{*}$ & 1 & & & & & & & \\
\hline $\begin{array}{l}\text { Web Experience } \\
\text { Satisfaction with Websites }\end{array}$ & $.544^{*}$ & $\begin{array}{l}.681^{*} \\
*\end{array}$ & 1 & & & & & & \\
\hline $\begin{array}{l}\text { Web Experience - Web } \\
\text { Shopping Compatibility }\end{array}$ & $\begin{array}{l}.498^{*} \\
*\end{array}$ & $\begin{array}{l}.602^{*} \\
*\end{array}$ & $.429^{*}$ & 1 & & & & & \\
\hline $\begin{array}{l}\text { Web Experience - Internet } \\
\text { Self Efficacy }\end{array}$ & $\begin{array}{l}.577^{*} \\
*\end{array}$ & $.446^{*}$ & 0.193 & $.626^{*}$ & 1 & & & & \\
\hline $\begin{array}{l}\text { Web Experience } \\
\text { Perceived Web Security }\end{array}$ & $\begin{array}{l}.563^{*} \\
*\end{array}$ & $\begin{array}{l}.592^{*} \\
*\end{array}$ & $.531^{* *}$ & 0.325 & $.438^{*}$ & 1 & & & \\
\hline $\begin{array}{l}\text { TAM - Perceived } \\
\text { Usefulness }\end{array}$ & $\begin{array}{l}.591^{*} \\
*\end{array}$ & $\begin{array}{l}0.26 \\
2\end{array}$ & 0.207 & $.486^{*}$ & $.852^{* * *}$ & $.472^{*}$ & 1 & & \\
\hline $\begin{array}{l}\text { TAM - Perceived Ease of } \\
\text { Use }\end{array}$ & $\begin{array}{l}.556^{*} \\
*\end{array}$ & $.454^{*}$ & 0.325 & $\begin{array}{l}.517^{*} \\
*\end{array}$ & $.784^{* * *}$ & $.574^{* *}$ & $.777^{* *}$ & 1 & \\
\hline $\begin{array}{l}\text { TAM - Attitude Towards } \\
\text { Shopping }\end{array}$ & $\begin{array}{l}.572^{*} \\
*\end{array}$ & $.468^{*}$ & 0.318 & $\begin{array}{l}.571^{*} \\
*\end{array}$ & $.843^{* * *}$ & $.640^{* *}$ & $.773^{* *}$ & $.802^{* *}$ & 1 \\
\hline
\end{tabular}

**. Correlation is significant at the 0.01 level (2-tailed).

*. Correlation is significant at the 0.05 level (2-tailed). 


\section{Discriminant Validity Test}

Discriminant Validity check is performed to ensure that the variables contained within a study are actually distinct from each other and are measuring different aspects from each other. To calculate the discriminant validity, the square root of the cumulative variance extracted is taken, and then checked against a correlation table to see whether if any all the values are below the calculated factor (Fornell \& Larcker, 1981).

In our data, we see that the above-mentioned condition is fulfilled, hence we conclude that discriminant validity is present in all of our construct variables.

Table 6: Discriminant Validity Test

\begin{tabular}{|c|c|c|c|c|c|c|c|c|c|}
\hline Constructs & $\begin{array}{l}\text { PT } \\
\text { OL }\end{array}$ & $\begin{array}{l}\text { PT } \\
\text { BUY }\end{array}$ & $\begin{array}{l}\text { WEB } \\
\text { SAT }\end{array}$ & $\begin{array}{l}\text { WEB } \\
\text { SC }\end{array}$ & $\begin{array}{l}\text { WEB } \\
\text { _ISE }\end{array}$ & $\begin{array}{l}\text { WEB } \\
\text { PWS }\end{array}$ & $\begin{array}{l}\text { TAM } \\
\text { PUSE }\end{array}$ & $\begin{array}{l}\text { TAM_P } \\
\text { EOU }\end{array}$ & $\begin{array}{l}\text { TAM } \\
\text { ATT }\end{array}$ \\
\hline $\begin{array}{l}\text { Personality Traits - Opinion } \\
\text { Leadership }\end{array}$ & 0.763 & & & & & & & & \\
\hline $\begin{array}{l}\text { Personality Traits - Buying } \\
\text { Impulsiveness }\end{array}$ & $.568^{* *}$ & 0.803 & & & & & & & \\
\hline $\begin{array}{l}\text { Web Experience - } \\
\text { Satisfaction with Websites }\end{array}$ & $.544^{* *}$ & $.681^{* *}$ & 0.738 & & & & & & \\
\hline $\begin{array}{l}\text { Web Experience - Web } \\
\text { Shopping Compatibility }\end{array}$ & $.498^{* *}$ & $.602^{* *}$ & $.429^{*}$ & 0.828 & & & & & \\
\hline $\begin{array}{l}\text { Web Experience - Internet } \\
\text { Self Efficacy }\end{array}$ & $.577^{* *}$ & $.446^{*}$ & 0.193 & $.626^{* *}$ & 0.910 & & & & \\
\hline $\begin{array}{l}\text { Web Experience - Perceived } \\
\text { Web Security }\end{array}$ & $.563^{* *}$ & $.592^{* *}$ & $.531^{* *}$ & 0.325 & $.438^{*}$ & 0.921 & & & \\
\hline TAM - Perceived Usefulness & $.591^{* *}$ & 0.262 & 0.207 & $.486^{*}$ & $.852^{* *}$ & $.472^{*}$ & 0.908 & & \\
\hline $\begin{array}{l}\text { TAM - Perceived Ease of } \\
\text { Use }\end{array}$ & $.556^{* *}$ & $.454^{*}$ & 0.325 & $.517^{* *}$ & $.784^{* *}$ & $.574^{* *}$ & $.777^{* *}$ & 0.794 & \\
\hline $\begin{array}{l}\text { TAM - Attitude Towards } \\
\text { Shopping }\end{array}$ & $.572^{* *}$ & $.468^{*}$ & 0.318 & $.571^{* *}$ & $.843^{* *}$ & $.640^{* *}$ & $.773^{* *}$ & $.802^{* *}$ & 0.888 \\
\hline
\end{tabular}

\section{Factor Analysis:}

When we examine the factor loadings, we see that why the Cronbach Alpha of the subconstruct of Satisfaction with Websites is dropping, when we examine the factor loading of WEB_SAT2 
(highlighted in red). The cumulative factor loadings of all the items in the research should be greater than 0.5 (Fornell \& Larcker, 1981) whereas the loading of WEB_SAT2 is below that threshold showing an impact as a reduced reliability score.

Unfortunately, WEB_SAT2 cannot be removed to increase the reliability of the construct since the condition of the construct cannot be fulfilled if there are only 2 items.

Table 7: Factor Analysis \& Calculation of AVE and CR

\begin{tabular}{|c|c|c|c|c|}
\hline Constructs & Items & Factor Loading & AVE & CR \\
\hline \multicolumn{5}{|l|}{ Personality Traits } \\
\hline \multirow[t]{7}{*}{ Opinion Leadership } & PT_OL1 & 0.587 & $58.16 \%$ & $90.23 \%$ \\
\hline & PT_OL2 & 0.414 & & \\
\hline & PT_OL3 & 0.896 & & \\
\hline & PT_OL4 & 0.901 & & \\
\hline & PT_OL5 & 0.707 & & \\
\hline & PT_OL6 & 0.816 & & \\
\hline & PT_OL7 & 0.881 & & \\
\hline \multirow[t]{4}{*}{ Buying Impulsiveness } & PT_BUY1 & 0.774 & $64.54 \%$ & $87.90 \%$ \\
\hline & PT_BUY2 & 0.810 & & \\
\hline & PT_BUY3 & 0.862 & & \\
\hline & PT_BUY4 & 0.764 & & \\
\hline
\end{tabular}

\section{Web Experience}

$\begin{array}{ccccc}\text { Satisfaction with Websites } & \text { WEB_SAT1 } & 0.947 & 54.48 \% & 74.36 \% \\ & \text { WEB_SAT2 } & 0.211 & & \\ & \text { WEB_SAT3 } & 0.833 & & \\ \text { Web Shopping Compatibility } & \text { WEB_SC1 } & 0.674 & 68.60 \% & 86.56 \% \\ & \text { WEB_SC2 } & 0.858 & & \\ & \text { WEB_SC3 } & 0.931 & \end{array}$


Internet Self Efficacy

Perceived Web Security

$\begin{array}{cc}\text { WEB_PWS1 } & 0.844 \\ \text { WEB_PWS2 } & 0.960 \\ \text { WEB_PWS3 } & 0.953\end{array}$

\section{Technology Acceptance Model}

Perceived Usefulness

Perceived Ease of Use

Perceived Usefulness

renger

Attitude Towards Shopping

$\begin{array}{cc}\text { WEB_ISE1 } & 0.959 \\ \text { WEB_ISE2 } & 0.854 \\ \text { WEB_ISE3 } & 0.935 \\ \text { WEB_ISE4 } & 0.890\end{array}$

WEB_PWS1 0.844
$84.74 \% \quad 94.32 \%$

$82.84 \% \quad 95.07 \%$

$\begin{array}{llll}\text { TAM_PUSE1 } & 0.933 & 82.52 \% & 93.40 \% \\ \text { TAM_PUSE2 } & 0.888 & & \\ \text { TAM_PUSE3 } & 0.904 & 62.97 \% & 83.28 \% \\ \text { TAM_PEOU1 } & 0.630 & & \\ \text { TAM_PEOU2 } & 0.927 & & \\ \text { TAM_PEOU3 } & 0.796 & 78.85 \% & 91.76 \% \\ \text { TAM_ATT1 } & 0.942 & & \\ \text { TAM_ATT2 } & 0.806 & & \\ \text { TAM_ATT3 } & 0.910 & & \end{array}$

\section{Regression Analysis}

In order to check the relationship of variables with other variables, we can use linear regression.

Table 8: Regression Analysis Summary

\section{Coefficient t-Statistic Hypothesis}

H1 H1a Personality Traits - Opinion Leadership
$\rightarrow$
0.163
1.131
Rejected

TAM - Perceived Usefulness 
H1b Personality Traits - Buying

Impulsiveness $\rightarrow$

$-0.409$

$-2.543 \quad$ Supported

TAM - Perceived Usefulness

H2 H2a Personality Traits - Opinion Leadership
$\rightarrow$
$-0.001$
$-0.007$
Rejected

TAM - Perceived Ease of Use

H2b Personality Traits - Buying

Impulsiveness $\rightarrow$

$-0.088$

$-0.421 \quad$ Rejected

TAM - Perceived Ease of Use

H3 H3a Web Experience - Satisfaction with

Websites $\rightarrow$

0.876

Rejected

TAM - Perceived Usefulness

H3b Web Experience - Web Shopping

Compatibility $\rightarrow$

0.135

Rejected

TAM - Perceived Usefulness

H3c Web Experience - Internet Self Efficacy

$\rightarrow$

Supported

TAM - Perceived Usefulness

H3d Web Experience - Perceived Web

Security $\rightarrow$

0.186

0.1378

Rejected

TAM - Perceived Usefulness

H4 H4a Web Experience - Satisfaction with

Websites $\rightarrow$

0.107

0.550

Rejected

TAM - Perceived Ease of Use 
H4b Web Experience - Web Shopping
Compatibility $\rightarrow$
0.014
0.072
Rejected

TAM - Perceived Ease of Use

H4c Web Experience - Internet Self Efficacy

$\rightarrow$

Supported

TAM - Perceived Ease of Use

H4d Web Experience - Perceived Web

Security $\rightarrow$

Rejected

TAM - Perceived Ease of Use

H5

TAM - Perceived Usefulness $\rightarrow$

Attitude Towards Shopping

Supported

H6

TAM - Perceived Ease of Use $\rightarrow$

Attitude Towards Shopping

We see that most of the t-statistics are below the value of 2.0, which means that they are susceptible to being rejected and for values that are greater than 2.0 will never be rejected (Montgomery \& Runger, 2014; Walpole \& Myers, 2012).

When we check our model using Linear Regression, we see that except Buying Impulsiveness, there is no relationship of Opinion Leadership to Perceived Ease of Use, but in contrast we see that there is no relation whatsoever with Perceived Ease of Use.

When we look at the Web Experiences, we see that except Internet Self Efficacy, there is no relationship between any of the subconstructs with Perceived Usefulness except Internet Self Efficacy. 
Coming to our $4^{\text {th }}$ hypothesis, we see that except for the relationship between internet selfefficacy, there is no relationship with any of the other subconstructs with Perceived Ease of Use.

For our Technology Acceptance Model, we see that all three constructs have a strong relationship between them, hence the hypotheses regarding a significant relationship of Perceived Usefulness and Perceived Ease of Use and between Attitude Towards Shopping does exist support our stated hypothesis.

The Regression Analysis was run in three steps:

1. Checking the relationship of Personality Traits and Web Experience with Perceived Usefulness $(\mathrm{H} 1, \mathrm{H} 3)$. We see that $81.3 \%$ of variation in Perceived Usefulness is explained by the model where Buying Impulsiveness is only significant.

Table 9: Regression (Personality, Web with Perceived Use)

\begin{tabular}{|c|c|c|c|c|c|c|c|}
\hline \multicolumn{8}{|c|}{ Model Summary } \\
\hline \multirow{2}{*}{$\mathbf{R}$} & \multirow{2}{*}{$\begin{array}{l}\mathbf{R} \\
\text { Square }\end{array}$} & \multirow{2}{*}{$\begin{array}{l}\text { Adjusted R } \\
\text { Square }\end{array}$} & \multirow{2}{*}{$\begin{array}{l}\text { Std. Error of } \\
\text { the Estimate }\end{array}$} & \multicolumn{4}{|l|}{ Change Statistics } \\
\hline & & & & R Square Change & F Change & df2 & Sig. F Change \\
\hline $.902^{\mathrm{a}}$ & 0.813 & 0.757 & 0.712 & 0.813 & 14.466 & 20 & 0.000 \\
\hline \multicolumn{8}{|c|}{$\begin{array}{l}\text { Predictors: (Constant), Web Experience - Perceived Web Security, Web Experience - Web Shopping } \\
\text { Compatibility, Web Experience - Satisfaction with Websites, Personality Traits - Opinion Leadership, } \\
\text { Web Experience - Internet Self Efficacy, Personality Traits - Buying Impulsiveness }\end{array}$} \\
\hline \multicolumn{8}{|c|}{ ANOVA $^{\mathrm{a}}$} \\
\hline & & \multicolumn{2}{|c|}{ Sum of Squares } & df & Mean Square & $\mathbf{F}$ & Sig. \\
\hline \multicolumn{2}{|c|}{ Regression } & \multicolumn{2}{|c|}{43.947} & 6 & 7.325 & 14.466 & $.000^{\mathrm{b}}$ \\
\hline \multicolumn{2}{|c|}{ Residual } & \multicolumn{2}{|c|}{10.127} & 20 & 0.506 & & \\
\hline \multicolumn{2}{|c|}{ Total } & \multicolumn{2}{|c|}{54.074} & 26 & & & \\
\hline
\end{tabular}

a. Dependent Variable: TAM - Perceived Usefulness

b. Predictors: (Constant), Web Experience - Perceived Web Security, Web Experience - Web Shopping Compatibility, Web Experience - Satisfaction with Websites, Personality Traits - Opinion Leadership, Web Experience - Internet Self Efficacy, Personality Traits - Buying Impulsiveness 


\begin{tabular}{llllll}
\hline & \multicolumn{2}{l}{$\begin{array}{l}\text { Unstandardized } \\
\text { Coefficients }\end{array}$} & \multicolumn{2}{l}{$\begin{array}{l}\text { Standardized } \\
\text { Coefficients }\end{array}$} & S \\
\cline { 2 - 7 } & B & \multicolumn{2}{l}{ Std. Error } & Beta & \\
\hline (Constant) & 0.041 & 0.688 & & 0.059 & 0.953 \\
Personality Traits - Opinion Leadership & 0.170 & 0.150 & 0.163 & 1.131 & 0.272 \\
Personality Traits - Buying Impulsiveness & -0.358 & 0.141 & -0.409 & -2.543 & 0.019 \\
Web Experience - Satisfaction with Websites & 0.146 & 0.167 & 0.132 & 0.876 & 0.392 \\
Web Experience - Web Shopping Compatibility & 0.021 & 0.152 & 0.020 & 0.135 & 0.894 \\
Web Experience - Internet Self Efficacy & 0.836 & 0.152 & 0.821 & 5.487 & 0.000 \\
Web Experience - Perceived Web Security & 0.149 & 0.108 & 0.186 & 1.378 & 0.183 \\
\hline
\end{tabular}

a. Dependent Variable: TAM - Perceived Usefulness

2. Checking the relationship of Personality Traits and Web Experience with Perceived Ease of Use $(\mathrm{H} 2, \mathrm{H} 4)$. We see that $68.6 \%$ of variation in Perceived Ease of Use is explained by the model where Internet Self Efficacy is only significant.

Table 10: Regression (Personality, Web with Perceived Ease of Use)

\section{Model Summary}

\begin{tabular}{|c|c|c|c|c|c|c|c|c|}
\hline \multirow[b]{2}{*}{$\mathbf{R}$} & \multirow[b]{2}{*}{$\begin{array}{l}\mathbf{R} \\
\text { Square }\end{array}$} & \multirow[b]{2}{*}{$\begin{array}{l}\text { Adjusted } \\
\text { R Square }\end{array}$} & \multirow{2}{*}{$\begin{array}{l}\text { Std. } \\
\text { Error of } \\
\text { the } \\
\text { Estimate }\end{array}$} & \multicolumn{5}{|l|}{ Change Statistics } \\
\hline & & & & R Square Change & F Change & df1 & df2 & Sig. F Change \\
\hline $.828^{\mathrm{a}}$ & 0.686 & 0.592 & 0.652 & 0.686 & 7.276 & 6 & 20 & 0.000 \\
\hline
\end{tabular}

a. Predictors: (Constant), Web Experience - Perceived Web Security, Web Experience - Web Shopping Compatibility, Web Experience - Satisfaction with Websites, Personality Traits - Opinion Leadership, Web Experience - Internet Self Efficacy, Personality Traits - Buying Impulsiveness

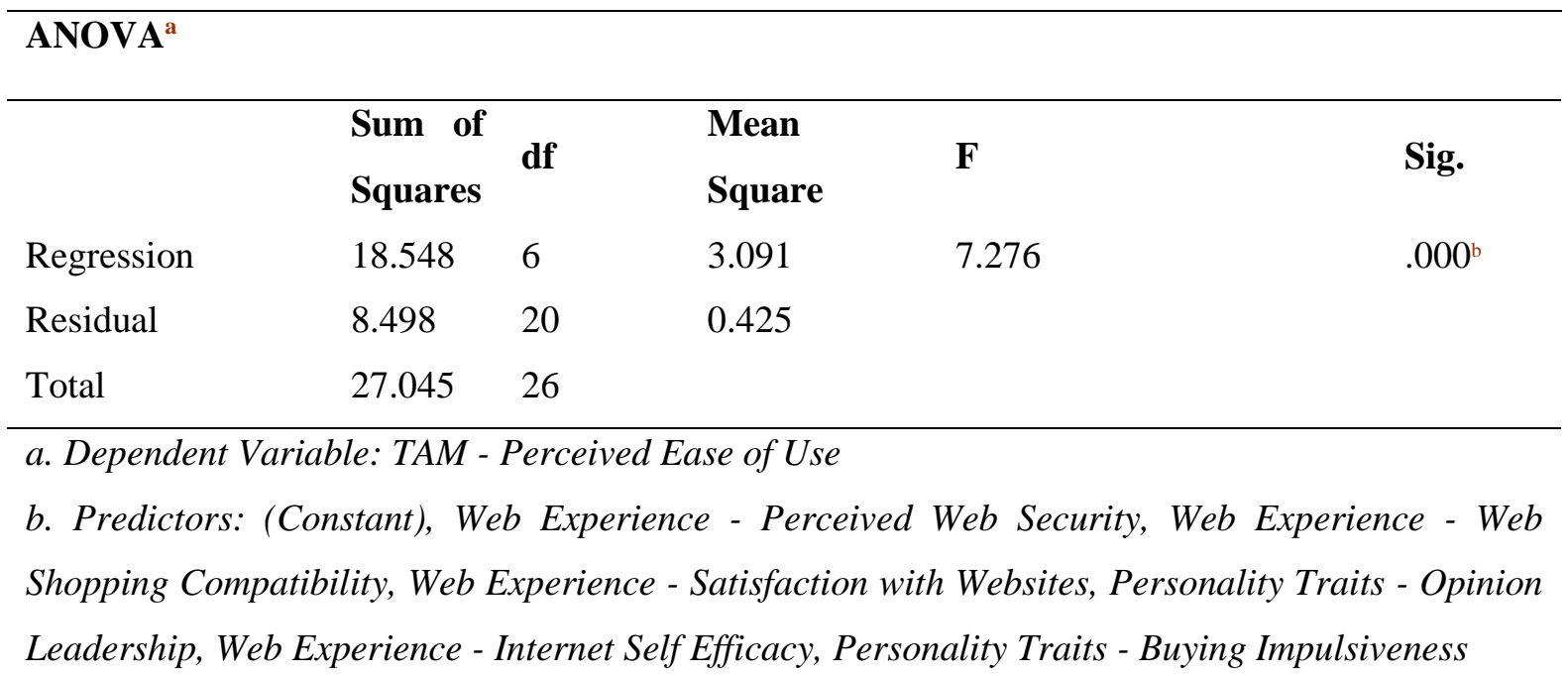




\section{Coefficients $^{\mathrm{a}}$}

\begin{tabular}{|c|c|c|c|c|c|}
\hline & \multicolumn{2}{|c|}{$\begin{array}{l}\text { Unstandardized } \\
\text { Coefficients }\end{array}$} & \multirow{2}{*}{$\begin{array}{l}\text { Standardized } \\
\text { Coefficients } \\
\text { Beta }\end{array}$} & \multirow[t]{2}{*}{$\mathbf{t}$} & \multirow[t]{2}{*}{ Sig. } \\
\hline & $\mathbf{B}$ & Std. Error & & & \\
\hline (Constant) & 1.829 & 0.630 & & 2.903 & 0.009 \\
\hline $\begin{array}{l}\text { Personality Traits - Opinion } \\
\text { Leadership }\end{array}$ & -0.001 & 0.138 & -0.001 & -0.007 & 0.994 \\
\hline $\begin{array}{l}\text { Personality Traits - Buying } \\
\text { Impulsiveness }\end{array}$ & -0.054 & 0.129 & -0.088 & -0.421 & 0.678 \\
\hline $\begin{array}{l}\text { Web Experience - Satisfaction } \\
\text { with Websites }\end{array}$ & 0.084 & 0.153 & 0.107 & 0.550 & 0.589 \\
\hline $\begin{array}{l}\text { Web Experience - Web } \\
\text { Shopping Compatibility }\end{array}$ & 0.010 & 0.139 & 0.014 & 0.072 & 0.943 \\
\hline $\begin{array}{l}\text { Web Experience - Internet } \\
\text { Self Efficacy }\end{array}$ & 0.488 & 0.140 & 0.677 & 3.495 & 0.002 \\
\hline $\begin{array}{l}\text { Web Experience - Perceived } \\
\text { Web Security }\end{array}$ & 0.152 & 0.099 & 0.268 & 1.533 & 0.141 \\
\hline
\end{tabular}

a. Dependent Variable: TAM - Perceived Ease of Use

3. Checking the relationship of Perceived Usefulness and Perceived Ease of Use with Attitude towards Shopping (H5, H6). We see that $70.0 \%$ of variation in Attitude Towards Online Shopping is explained by the model where Perceived Usefulness and Perceived Ease of use both are significant.

Table 11: Regression (Perceived Usefulness, Perceived Ease of Use with Attitude)

\begin{tabular}{|c|c|c|c|c|c|c|c|c|}
\hline \multicolumn{9}{|c|}{ Model Summary } \\
\hline \multirow[b]{2}{*}{$\mathbf{R}$} & \multirow{2}{*}{$\begin{array}{l}\mathbf{R} \\
\text { Square }\end{array}$} & \multirow{2}{*}{$\begin{array}{l}\text { Adjusted } \\
\text { R Square }\end{array}$} & \multirow{2}{*}{$\begin{array}{l}\text { Std. Error } \\
\text { of the } \\
\text { Estimate } \\
\end{array}$} & \multicolumn{5}{|l|}{ Change Statistics } \\
\hline & & & & R Square Change & F Change & df1 & df2 & Sig. F Change \\
\hline $.837^{\mathrm{a}}$ & 0.700 & 0.675 & 0.676 & 0.700 & 27.979 & 2 & 24 & 0.000 \\
\hline
\end{tabular}

a. Predictors: (Constant), TAM - Perceived Ease of Use, TAM - Perceived Usefulness

\begin{tabular}{llllll}
\hline ANOVA $^{\mathrm{a}}$ & \multicolumn{1}{l}{} \\
\hline & Sum of Squares & df & Mean Square & F & Sig. \\
Regression & 25.557 & 2 & 12.779 & 27.979 & $.000^{\mathrm{b}}$ \\
Residual & 10.961 & 24 & 0.457 & & \\
Total & 36.519 & 26 & & & \\
\hline
\end{tabular}

a. Dependent Variable: TAM - Attitude Towards Shopping

b. Predictors: (Constant), TAM - Perceived Ease of Use, TAM - Perceived Usefulness 


\begin{tabular}{llllll} 
Coefficients $^{\mathbf{a}}$ & \multicolumn{2}{l}{$\begin{array}{l}\text { Unstandardized } \\
\text { Coefficients }\end{array}$} & $\begin{array}{l}\text { Standardized } \\
\text { Coefficients }\end{array}$ & t & Sig. \\
\cline { 2 - 7 } & B & Std. Error & Beta & & \\
\hline (Constant) & 0.341 & 0.716 & & 0.476 & 0.639 \\
TAM - Perceived Usefulness & 0.312 & 0.146 & 0.380 & 2.135 & 0.043 \\
TAM - Perceived Ease of Use & 0.589 & 0.207 & 0.507 & 2.850 & 0.009 \\
\hline
\end{tabular}

a. Dependent Variable: TAM - Attitude Towards Shopping

\section{DISCUSSION AND CONCLUSION}

Through the conducting of this study, it was tried to explain the relationship of different factors such as the personality traits and the web experiences of an online shopper with the technology acceptance models perceived ease of use, perceived usefulness and finally to the attitude towards online shopping, and to see whether or not the sample size that was chosen to conduct our research has a positive attitude towards online shopping.

\section{Hypothesis 1}

Hypothesis 1 stated that Personality had a significant effect on Perceived Usefulness. When we checked the relationship between the two variables, we saw that just one subconstruct Buying Impulsiveness had a significant negative relationship with Perceived Usefulness, which indicates that the more useful they find any online shopping service, they are less likely to show signs of impulsive buying and try to make well informed decisions. Hence, the hypothesis 1 was partially supported.

\section{Hypothesis 2}

Hypothesis 2 stated that Personality had a significant effect on Perceived Ease of Use. In our data analysis tests, we see that both the Opinion Leadership and the Buying Impulsiveness did not have any significant effect on Perceived Ease of Use which indicates that no matter how user-friendly an online shopping portal will become, it will not be able to benefit from our respondents buying impulsiveness or opinion leadership traits, which means that they will be cautious and completely aware during online shopping. Hence, the hypothesis 2 was partially supported. 


\section{Hypothesis 3}

Hypothesis 3 stated that Web Experiences had a significant effect on Perceived Usefulness. When the analysis was conducted, it was seen Internet Self Efficacy had a significant impact on Perceived Usefulness, leading to believe that self-efficacy is a necessary component to be present in online shoppers in order to make calculated decisions when the online portal they are using is supposed to provide some benefit for them in return. If a person is not self-confident that he/she is able to exert control, they will not be able to properly use any online shopping portal for their needs, especially considering that they do not need to be satisfied with any website, or have any skill in online shopping, or even concerned about online security. Hence, the hypothesis 3 was partially supported.

\section{Hypothesis 4}

Hypothesis 4 stated that Web Experiences had a significant effect on Perceived Ease of Use. Upon conducting the analysis, the only significant relationship found was the same contributor to Hypothesis 3, which was Internet Self-Efficacy. When it comes to user friendliness, we see a relationship that if a person is confident, they are highly likely to find an online shopping platform user-friendly as well, but our research also shows that no matter how security conscious a person is, or how good is that person is in online shopping itself, it does not have any relationship and hence will not find the online shopping platform user-friendly, and will look past those properties. Hence, the hypothesis 4 was partially supported.

\section{Hypothesis 5}

Hypothesis 5 stated that Perceived Usefulness had a significant relationship on Attitude Towards Online Shopping, and our results also found the same, hence also supporting our claimed hypothesis.

Studies other than this one which even data back to the original technology acceptance model (Bashir, 2013; Jiang et al., 2013) have shown that if a system is shown to be useful to any 
potential person, he/she will also find it easier to intend to use it, or in our case will also find it likeable to intend to use a certain online shopping platform. Hence, our hypothesis 5 is stands completely supported.

\section{Hypothesis 6}

Hypothesis 6 stated that Perceived Ease of Use had a significant relationship on Attitude Towards Online Shopping, and as like in the case with Perceived Usefulness, our analysis also yields a significant relationship with the attitude towards online shopping.

Further studies (Burney et al., 2017; Szajna, 1996) have shown that this relationship does exist and is also deemed to be significant in most literatures as well. This is also logical since if a person finds any online shopping platform to be user friendly, he/she will develop a natural liking to it since it saves them time, or is easy to understand, hence they will form an intent to come back to it more often. Hence, our hypothesis 5 is completely supported.

\section{CONCLUSION}

The premise of this study was to study people who use online shopping in such a way as to profile them. How this helped is to create a general understanding of what attitude do online shoppers have in common, and how the online shopping platforms should adjust their portals in order to further facilitate their potential users and furthermore to make sure that the system is primed so that they always come back.

We see that in our case online shoppers come in different types, but they are not mostly swayed by any online shopping platforms ease of use or the usability that they can get out of it. But they do show that they are swayed by the fact that if a system proves to be useful to them and at the same time is also user friendly, they will inadvertently also form an intention to use that particular platform. 


\section{RECOMMENDATIONS \& FUTURE DIRECTIONS}

This study only used a mere 27 respondents to study a phenomenon that requires far greater respondents to study. For a successful study, the sample size is of the utmost importance in order to properly study the effect and relationships, and for a study of this size, the number of minimum respondents range from 150 (Sekeran, 2003) to around 300 respondents to firmly reject or support any hypothesis. Hence, this study can be reperformed in such a way that the data analysis can incorporate a much larger sample size.

Furthermore, the technology acceptance model has a lot of facets to it, and incorporating one or more of those mediating or moderating variables will help in achieving a more broadspectrum data analysis that can assist online shopping platforms in making their online store more suited to all of their potential buyers. 


\section{REFERENCES}

Alibaba Group. (n.d.). Retrieved December 20, 2020, from https://www.alibabagroup.com/en/global/home

Bashir, A. (2013). Consumer Behavior towards Online Shopping of Electronics in Pakistan.

Beatty, S. E., \& Ferrell, M. E. (1998). Impulse Buying: Modeling Its Precursors.

Bell, E., Bryman, A., \& Harley, B. (2018). Business research methods. Oxford university press.

Burney, S. A., Ali, S. A., Ejaz, A., Siddiqui, F. A., \& S.M. Aqil Burney, Syed Asim Ali, Afshan Ejaz, F. A. S. (2017). Discovering the Correlation between Technology Acceptance Model and Usability. IJCSNS International Journal of Computer Science and Network Security, 17(11), 53-61. http://paper.ijcsns.org/07_book/201711/20171107.pdf

Daraz.pk Analytics - Market Share Data \& Ranking|SimilarWeb. (n.d.). Retrieved December 20, 2020, from https://www.similarweb.com/website/daraz.pk/

Davis, F. D. (1989). Perceived usefulness, perceived ease of use, and user acceptance of information technology. MIS Quarterly: Management Information Systems, 13(3), 319339. https://doi.org/10.2307/249008

Davis, F. D. (1993). User acceptance of information technology: system characteristics, user perceptions and behavioral impacts. International Journal of Man-Machine Studies, 38(3), 475-487. https://doi.org/https://doi.org/10.1006/imms.1993.1022

Davis, F. D., \& Venkatesh, V. (1996). A critical assessment of potential measurement biases in the technology acceptance model: Three experiments. International Journal of Human Computer Studies, 45(1), 19-45. https://doi.org/10.1006/ijhc.1996.0040

Donthu, N., \& Gilliland, D. (1996). The infomercial shopper. Journal of Advertising Research, $36(2), 69-77$.

Fornell, C., \& Larcker, D. F. (1981). Evaluating structural equation models with unobservable variables and measurement error. Journal of Marketing Research, 18(1), 39-50.

Forsythe, S., Liu, C., Shannon, D., \& Gardner, L. C. (2006). Development of a scale to measure the perceived benefits and risks of online shopping. Journal of Interactive Marketing, $20(2), 55-75$.

Gentry, J. W., \& Dickerson, M. D. (1983). Characteristics of Adopters and Non-Adopters of Home Computers. Article in Journal of Consumer Research. https://doi.org/10.1086/208961

Hair, J. F., Black, B., \& Babin, B. A. (2006). RE, \& Tatham, RL (2006). Multivariate Data Analysis, 6.

Jiang, L. (Alice), Yang, Z., \& Jun, M. (2013). Measuring consumer perceptions of online shopping convenience. Journal of Service Management, 24(2), 191-214. https://doi.org/10.1108/09564231311323962 
Lederer, A. L., Maupin, D. J., Sena, M. P., \& Zhuang, Y. (1997). Association for Information Systems AIS Electronic Library (AISeL) TAM and the World Wide Web Recommended Citation TAM and the World Wide Web (Vol. 258). http://aisel.aisnet.org/amcis1997http://aisel.aisnet.org/amcis1997/258

Liker, J. K., \& Sindi, A. A. (1997). User acceptance of expert systems: a test of the theory of reasoned action. Journal of Engineering and Technology Management, 14(2), 147-173. https://doi.org/https://doi.org/10.1016/S0923-4748(97)00008-8

Montgomery, D. C., \& Runger, G. C. (2014). Applied statistics and probability for engineers. Wiley.

Moon, J.-W., \& Kim, Y. G. (2001). Extending the TAM for a World-Wide-Web context. Information \& Management, $38(4), \quad 217-230$. https://doi.org/https://doi.org/10.1016/S0378-7206(00)00061-6

O'Cass, A., Fenech, T., O'Cass, A., \& Fenech, T. (2003). Web retailing adoption: exploring the nature of internet users Web retailing behaviour. Journal of Retailing and Consumer Services, 10(2), 81-94. https://doi.org/https://doi.org/10.1016/S0969-6989(02)00004-8

Pakistani Market: E-commerce. (n.d.). Retrieved December 20, 2020, from https://importexport.societegenerale.fr/en/country/pakistan/ecommerce

Santos, J. R. A. (1999). Cronbach's alpha: A tool for assessing the reliability of scales. Journal of Extension, 37(2), 1-5.

Sekeran, U. (2003). Research methods for business . Hoboken. NJ: John Wiley \& Sons. The Journal of Management Development.

Szajna, B. (1996). Empirical evaluation of the revised technology acceptance model. Management Science. https://doi.org/10.1287/mnsc.42.1.85

Venkatesh, V., \& Bala, H. (2008). Technology acceptance model 3 and a research agenda on interventions. Decision Sciences, 39(2), 273-315. https://doi.org/10.1111/j.15405915.2008.00192.x

Venkatesh, V., \& Davis, F. D. (2000). Theoretical extension of the Technology Acceptance Model: Four longitudinal field studies. Management Science, 46(2), 186-204. https://doi.org/10.1287/mnsc.46.2.186.11926

Walpole, R. E., \& Myers, R. H. (2012). Probability \& statistics for engineers \& scientists. Pearson Education Limited.

Yu, J., Ha, I., Choi, M., \& Rho, J. (2005). Extending the TAM for a t-commerce. Information \& Management, 42(7), 965-976. https://doi.org/https://doi.org/10.1016/j.im.2004.11.001 